\title{
Some Properties of High Strength Sustainable Concrete Containing Glass Powder Waste
}

\author{
Wasan I. Khalil ${ }^{1}$, Nazar F. Al-Obeidy ${ }^{2}$ \\ ${ }^{1}$ Professor, Building and Construction Engineering Department, University of Technology, \\ ${ }^{2}$ National Center for Construction Laboratories \\ wasan1959@yahoo.com.
}

\begin{abstract}
This investigation includes the use of glass wastes after recycling to produce high strength sustainable concrete. The glass waste used is prepared to be a natural Pozzolan class $(\mathrm{N})$ according to ASTM C618 with fineness of about $7340 \mathrm{~cm}^{2} / \mathrm{gm}$. Many concrete mixes with different percentages of glass waste powder as a partial replacement by weight of cement $(10 \%, 15 \%, 20 \%, 25 \%$, and $30 \%)$ were prepared to study some properties of concrete (compressive strength, splitting tensile strength, flexural strength, and modulus of elasticity at 60 day age). The test results indicate that the mechanical properties of concrete are improved with the increase of glass waste powder up to $15 \%$, and then decreased. The maximum percentages of increase for compressive, splitting tensile, flexural strengths, and modulus of elasticity are $13.29 \%, 36.27 \%, 34.68 \%$, and $8.2 \%$ respectively relative to the reference for concrete specimens containing $15 \%$ glass waste powder as a replacement by weight of cement. Corrosion inhibition of low carbon steel, stainless steel types 316 and 304 in hydrochloric acid by potassium iodide was investigated at different temperatures using weight loss and polarization electrochemical techniques
\end{abstract}

Keywords: high strength concrete, sustainable concrete, glass waste powder.

Paper History: Received: (26/10/2016), Accepted: (19/12/2016)

\section{1- Introduction}

High energy is needed to produce cement, which release large amounts of carbon dioxide $\mathrm{CO}_{2}$. Also, large amount of glass waste are disposed in landfill sites because of the large use of these products that leads to increase costs and environmental problems. The environmental advantages of glass powder that used as a replacement to cement including, conversion of non-recycled waste glass from landfills to useful applications, reduction the negative effects of cement production such as the consumption of natural resources, reducing energy and the emission of greenhouse gasses, improving concrete mechanical properties, and reducing the cost of concrete industry.
Therefore the use of recycled glass waste in concrete instead of cement gives a lot of interest $[1,2]$. Early researches focused on the use of glass waste in concrete as partial or full replacement to fine or coarse aggregate. These early trails are unsuccessful because of the alkali- silica reaction (ASR) which takes place between glass waste and concrete and leads to deterioration of concrete with time $[3,4,5,6]$. In order to overcome the alkali- silica reaction several treatment methods were used including, mechanical method by reducing the particle size of glass waste, or chemical method by using lithium compound to reduce the alkali- silica reaction expansion.

Keryon [6] used the local glass waste from windows glass with different percentages of $0 \%, 20 \%, 25 \%$, and $30 \%$ as a partial replacement to coarse aggregate by weight. The results indicate that using glass waste leads to a decrease in the fresh density and slump values, while the compressive strength, flexural strength and splitting tensile strength are enhanced. The optimum percentage of replacement is $25 \%$ by weight. At this percentage, the increase in the compressive strength, splitting strength, and flexural strength are $30 \%, 38 \%$, and $31 \%$ respectively relative to the reference specimens without glass waste.

Al-Obeidy and Khalil [7] investigated the effect of glass waste powder as a partial replacement to cement (by weight) on some properties of concrete. The different percentages of glass waste $(10 \%, 15 \%, 20 \%, 25 \%$, and $30 \%)$ were conducted to study the properties of concrete such as, fresh density, compressive strength at $7,28,60$, and 90 day age, and water absorption at 60 day age relative to the reference concrete mix specimens without glass waste powder. The compressive strength for concrete specimens with $10 \%, 15 \%$ glass waste powder at 28 , and 60 day age is increased. As the content of glass waste powder is increased to $20 \%, 25 \%$, and $30 \%$, the compressive strength is decreased. The maximum percentages increase in compressive strength are $1.17 \%$, $13.3 \%, 19.34 \%$ for specimens with $15 \%$ glass powder waste at 28,60 and 90 day age respectively, while the water absorption is decreased. The optimum percentage of glass powder is $15 \%$ as a partial replacement to 
cement, while the practical time of curing is 60 days age. This research provides the use of glass waste after grinding to particle size less than $75 \mu \mathrm{m}$ as a replacement of cement by $15 \%$ in concrete and investigated its other properties at 60 day age.

\section{2- Experimental Program}

\section{Properties of Materials \\ Cement}

Ordinary Portland cement type (I) with commercial mark (Al Mass) was used in this investigation. The test results show that the cement used is compatible with Iraqi Standards No. $5 / 1984$. The cement is protected in sealed plastic containers to avoid exposure to the weather. The chemical and physical properties of the cement used are given in Tables 1 and 2 respectively.

\section{Natural Fine Aggregate}

Natural sand brought from Al-Ukhaider region with maximum aggregate size of $4.75 \mathrm{~mm}$ was used. The sieve analysis and physical properties of this fine aggregate are presented in Table 3. The test results demonstrate that the used fine aggregate is within the requirements of the Iraqi Standard No.45/1980.

\section{Natural Coarse Aggregate}

Natural crushed coarse aggregate of nominal maximum size of $14 \mathrm{~mm}$ was used in this study. It was brought from AL-Badrah region. The properties of the natural coarse aggregate used are shown in Table 4. The results indicate that the grading and sulphate content of the coarse aggregate satisfy the requirements of Iraqi Standard No. 45/ 1980.

\section{Water}

The water used for mixing and curing of concrete was potable water from the water supply network (tap water).

\section{High-Range Water Reducing Admixture}

A high range water-reducing admixture (superplasticizer) with a commercial mark of GLENIUM 54 was used. The recommended dosage by the manufacturer was in the range of $0.5-2.5$ liters $/ 100 \mathrm{~kg}$ of the cement. This type of admixture is free from chlorides and is compatible with ASTM C494-04 type F. Table 5 gives the main properties of this superplasticizer.
Glass Powder Waste

Preparation

White glass were collected, washed, broken into small pieces, crushed and grinded into powder as shown in Figure 1.

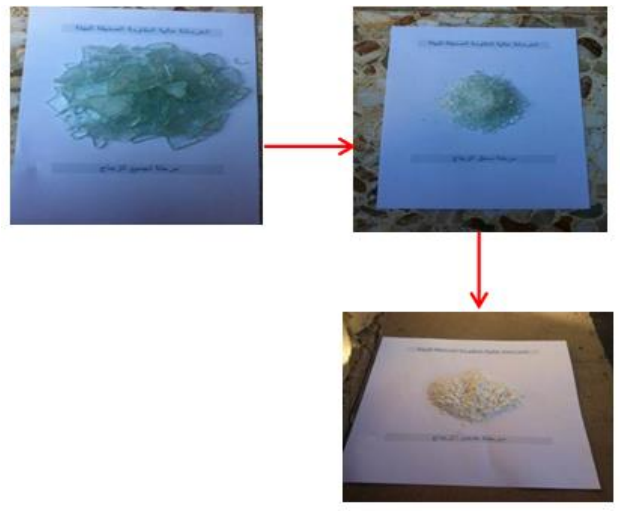

Figure 1: Preparation of Glass Powder.

\section{Properties of Glass Powder}

In previous research [7], the properties of the prepared glass powder were investigated. The results show that the fineness of the glass powder is $7340 \mathrm{~cm}^{2} / \mathrm{gm}$ tested accordance to ASTM C-204 (Blain method). The results in Table 6 show, that 10 minutes grinding period gives the highest fineness for glass waste powder. The results in Table 7 show the strength activity index of glass waste powder at 28 day age is $81 \%$, The remaining on sieve 45 microns (No. 325) is $9.88 \%$, and the amount of silica and alumina with the ferric oxides is about $90 \%$ are within the limits of ASTM C-618. The specific gravity of glass powder is 2.265. According to these results glass waste powder is classified as a natural Pozzolan according to ASTM C618.

\section{Selection of Mix Proportions for the Reference Concrete Mix}

In previous research [7], reference concrete mix was designed in according to British method for concrete mix design, to obtain concrete with minimum compressive strength of $40 \mathrm{MPa}$ at 28 day age without any admixtures. The mix proportions are 1:1.4:1.8 (cement: sand: gravel) by weight, with cement content of $500 \mathrm{~kg} / \mathrm{m}^{3}$, w/c ratio of 0.42 , and slump value of $100 \pm 5$ $\mathrm{mm}$. Several trial mixes were carried out to select the optimum dosage of high range water reducing admixture (HRWRA). The w/c ratio was adjusted to have the same workability of the reference mix (slump of $100 \pm 5 \mathrm{~mm}$ ). The main task of using HRWRA is to reduce the quantity of mixing water, while keeping the same workability of reference mix. The details of the designed reference concrete mix containing various dosages of superplasticizer (HRWRA) are given in Table 8 and shown in Figure 2. 
According to the manufacturer the recommended dosage of HRWRA is between 0.5 and 2.5 liters per $100 \mathrm{~kg}$ of cement. The experimental results in this investigation indicate that the optimum dosage of HRWRA is 1.5 liters per $100 \mathrm{~kg}$ of cement, which leads to a water reduction of about $35.71 \%$ and maximum compressive strength of $59.6 \mathrm{MPa}$ at age 28 day. The optimum dosage of high range water reducer which gives the highest compressive strength is $1.5 \% / 100 \mathrm{~kg}$ cement.

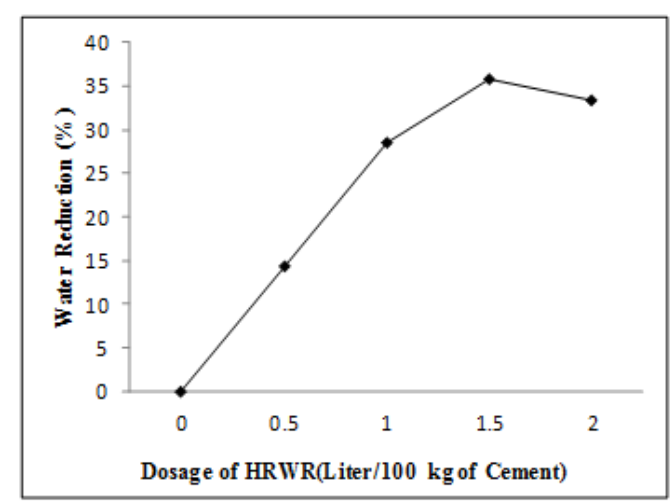

Figure 2: Relationship Between the Different Dosages of HRWRA and Water Reduction of Concrete Mix

\section{Mixing, Casting and Curing of Concrete Specimens}

The mixing process was performed in an electrical rotary vessel mixer of $0.1 \mathrm{~m}^{3}$ capacity. For concrete mixes containing glass waste powder the coarse and fine aggregate were in saturated and surface dry (SSD) conditions and mixed for one minute. Cement and glass waste powder were mixed by hand for five minutes, and then $60 \%$ of the mixing water was added to the dry mixture and mixed for one minute. The superplasticizer was mixed with the $40 \%$ remaining mixing water, then added to the mix and mixed for two minutes.

The steel molds were cleaned and their internal surfaces were lubricated with oil. The molds were filled with concrete and compacted by a vibrating table according to ASTM C192/C192M, to remove any entrapped air. After compaction, the specimens were leveled by hand troweling, covered with polyethylene, and left for 24 hours. The specimens were removed from molds, and they were completely submerged in water containing $3 \mathrm{gm} / \mathrm{liter}$ of calcium hydroxide according to ASTM C511. Concrete specimens were cured till the time of test.

\section{Experimental Tests}

The experimental tests that carried out in this investigate are the followings:

- Compressive, strength test according to B.S. 1881. This test was carried out on concrete cubes specimens of $100 \mathrm{~mm}$. The average value of three specimens was recorded for each concrete mix at 60 day age.

- Splitting tensile strength test according to ASTM C496. The average splitting tensile strength value for three cylinders $(200 \mathrm{~mm}$ height and $100 \mathrm{~mm}$ diameter) was computed at 60 day age.

- Flexural strength (modulus of rupture) test under two point loads according to ASTM C78. The average modulus of rupture for three prismatic specimens (100 x 100 x $400 \mathrm{~mm}$ ) was computed at 60 day age.

- Static modulus of elasticity test was carried out according to ASTM C469. Three Concrete cylinders of $300 \mathrm{~mm}$ height and $150 \mathrm{~mm}$ diameter were tested at 60 day age and the average value was calculated.

\section{Results and Discussion}

\section{Compressive Strength}

The test results in Table 9 and Figure 3 show that the reference concrete (without glass powder) prepared in this investigation is high strength concrete with compressive strength of 64.7 MPa at 60 day age [8]. The compressive strength increases to 66.1 and $73.3 \mathrm{MPa}$ for specimens containing $10 \%$ and $15 \%$ glass powder as a replacement to cement by weight respectively at 60 day age. When the percentage of glass powder is increased over $15 \%$, the compressive strength is reduced compared with the reference specimens. The increase of compressive strength is due to the pozzolanic reaction that has been occurred, as a result of this reaction additional gel is produced, and thus the strength is improved $^{[9,10]}$. The increase of glass powder above the optimum content $(15 \%)$ may be leads to increase the active silica in the microstructure of concrete with the depletion of calcium hydroxide as a result of pozzolanic reaction. The remaining amount of free silica may cause weakness in the concrete structure and reduces the strength. The test results show that concrete specimens with $15 \%$ glass powder as a replacement of cement gave the maximum compressive strength. 


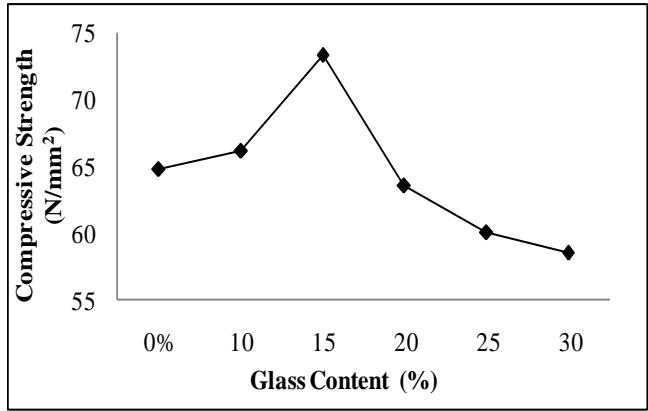

Figure 3: Effect of Glass Powder Content on the Compressive Strength of Concrete.

\section{Splitting Tensile Strength}

Values of splitting tensile strength at 60 day age of concrete specimens with various percentages of glass powder as partial replacement to cement are shown in Table 9 and Figure 4. The results demonstrate a clear increase in splitting tensile strength of concrete containing $10 \%$, $15 \%$, and $20 \%$ glass powder of about $3.27 \%$, $36.27 \%$, and $23.17 \%$ respectively compared with the reference concrete. This is due to the formation of extra gel from the pozzolanic reaction, in addition, glass powder fills the spaces between particles and increase the bond strength between the components of concrete ${ }^{[10}$, 11]. When the percentage replacement of glass powder increases to $25 \%, 30 \%$, the tensile strength reduces by about $11.33 \%, 19.14 \%$ respectively relative to the reference. This may be due to the reaction of calcium hydroxide with part of silica in glass powder and the survival amount of free silica in the microstructure of concrete reduces the bond between concrete components. The maximum splitting tensile strength is recorded for concrete containing $15 \%$ glass powder as a replacement by weight of cement.

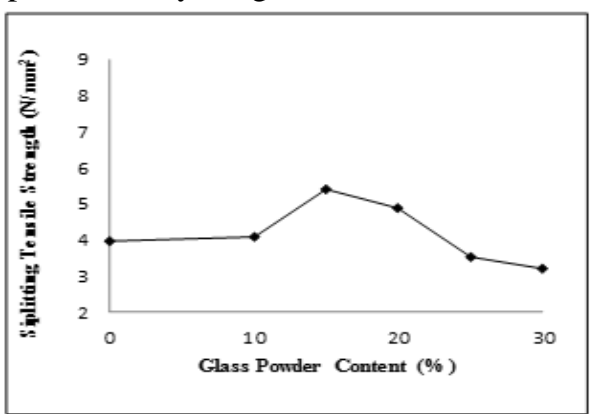

Figure 4: Effect of Glass Powder Content on Splitting Tensile Strength of Concrete.

\section{Flexural Strength}

The flexural strength results of concrete at 60 day age with different percentages of glass powder are presented in Table 9 and Figure 5. The results indicate that the flexural strength increases for concrete containing 10\%, 15\%, and $20 \%$ glass powder as a partial replacement of cement by weight. The highest increment is $34.68 \%$ for specimens with $15 \%$ glass powder compared with the reference. This increase is because glass powder improves the transition zone between aggregate and cement paste consequently due to the pozzolanic reaction, as well as its filling ability to the voids in the microstructure of concrete by extra gel produced from this reactions that reduces the porosity, which is inversely proportion with the strength of concrete [12, 13]. The reduction of flexural strength for specimens with $25 \%$ and $30 \%$ of glass powder are $12.23 \%$ and $18.84 \%$ respectively. This may be attributed to the depletion of calcium hydroxide due to the pozzolanic reaction. The survival part of free silica in the microstructure of concrete may be reduces the strength and the bond between the components of concrete. Concrete containing $15 \%$ glass powder has the maximum flexural strength.

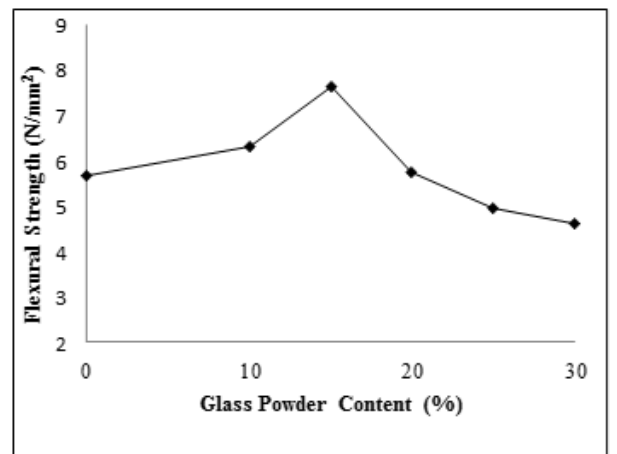

Figure 5: Effect of Glass Powder Content on Flexural Strength of Concrete.

\section{Static Modulus of Elasticity}

Table 9 and Figure 6 show the values of static modulus of elasticity for concrete with different percentages of glass powder as a replacement to cement at 60 day age. The results indicate a slight increase in modulus of elasticity for specimens containing $10 \%, 15 \%$, and $20 \%$ glass powder relative to the reference. The highest increment $(8.2 \%)$ in modulus of elasticity is for specimens with $15 \%$ glass powder. This is because there is a direct relationship between the compressive strength and modulus of elasticity ${ }^{[9,13]}$. The increase in content of glass powder to $25 \%$ and $30 \%$ causes a slight reduction in modulus of elasticity of about $3.1 \%$ and $7.92 \%$ respectively. This is because the compressive strength is also decreased.

Generally, all the results show that the optimum content of glass powder which improves the properties of concrete is $15 \%$ as a replacement by weight of cement. 


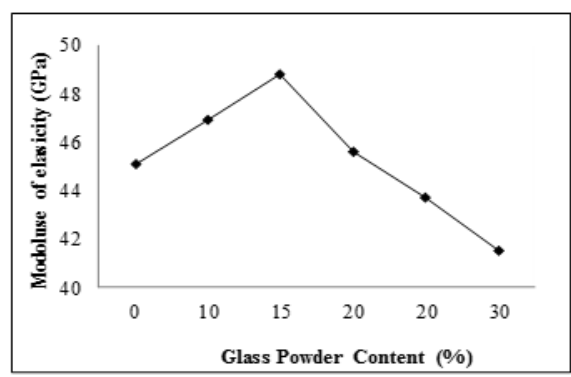

Figure 6: Effect of Glass Powder Content on the Static Modulus of Elasticity of Concrete.

\section{Conclusion}

The following conclusions can be drawn from the experimental results presented in this investigation:

1- Glass powder with particles size less than 75 micron behaves as a natural pozzolanic material type $(\mathrm{N})$ that improves the mechanical properties of concrete.

2- The use of glass powder as a replacement by weight of cement up to $15 \%$ increases the compressive strength at later ages (60 day age). The increment percentages are $2.16 \%$ and $13.29 \%$ for specimens containing $10 \%$ and $15 \%$ glass powder respectively relative to the reference specimens.

3- The increase of glass powder content more than $15 \%$ shows reduction in compressive strength of concrete. The percentages reduction are $1.85 \%, 7.26 \%$, and $9.73 \%$ for concrete specimens with $20 \%, 25 \%$, and $30 \%$ glass powder respectively compared with the reference specimens.

4- The use of glass powder as a replacement by weight of cement up to $20 \%$ enhances the, splitting tensile strength, flexural strength, and static modulus of elasticity of concrete in comparison with the reference specimens, while the increase of glass powder content more than $20 \%$ decreases all these properties.

6 - The optimum content of glass powder in concrete is $15 \%$ as a replacement by weight of cement. The percentages increase in compressive strength, splitting tensile strength, flexural strength, and static modulus of elasticity of concrete containing $15 \%$ glass powder are $13.29 \%, 36.27 \%, 34.68 \%$, and $8.2 \%$ respectively relative to the reference concrete.

\section{References}

[1]. Khatib, J.M., Negim, E.M., Sohl, H.S., and Chileshe, N., Glass Powder Utilization in Concrete Production, European Journal of Applied Sciences 2 (2012) 173-176.

[2]. Federico, L.M. and Chidiac, S.E., Waste Glass as a Supplementary Cementitious Material in Concrete -
Critical Review of Treatment Methods, Cement and Concrete Composites 31 (2009) 606-610.

[3]. Topcu, I. B., and Canbaz, M., Properties of Concrete Containing Waste Glass, Cement and Concrete Research 34 (2004) 267-274.

[4]. Vrivastava, V., Gantarn, S.P., Agarwal, V. C., and Mehta, P. K., Glass Wastes as Coarse Aggregate in Concrete, Journal of Nano Technology 3 (2014) 67-71.

[5]. Idir, R., Cyr, M., Tagnit-Hamou, A., Use of Fine Glass as ASR Inhibitor in Glass Aggregate Mortar, Construction and Building Materials 24 (2010) 1309-1312.

[6]. Keryon, A. B., Effect of Using Windows Waste Glass as Coarse Aggregate on some Properties of Concrete, Engineering and Technical Journal 32 (2014) 1519-1529.

[7]. Al-Obeidy, N.F., and Khalil, W.I., Properties of High Strength EcoFriendly Concrete with Glass Waste Powder, Global Journal of Engineering Science and Researches 3 (2016) 43-53.

[8]. American Concrete Institute Committee ACI 363, State-of-the-Art Report on High-Strength Concrete, 1992.

[9]. Neville, A.M., Properties of Concrete, 4th and Final Edition, Longman, 2005.

[10]. Thomas, M., Supplementary Cementing Materials in Concrete, Taylor and Francis Group, 2013.

[11]. Mindess, S., Young, J.F., Darwin, D., Concrete, Second Edition, Prentice Hall, 2003.

[12]. Newman, J., and Choo, B.S., Advanced Concrete Technology Constituent Materials, Butterworth Heinemann, An imprint Elsevier, First published, 2003.

[13].Mehta, P.K., and Monterio, P.J.M., Concrete Microstructure Properties and Materials, Third Edition, New York, 2006. 
Table 1 Chemical Composition and the Main Compounds of Cement Used in this Investigation.*

\begin{tabular}{|c|c|c|}
\hline Oxide Composition & Content $(\%)$ & $\begin{array}{l}\text { Limits of Iraqi Standard } \\
\text { No. } 5 / 1984\end{array}$ \\
\hline Lime $(\mathrm{CaO})$ & 64.62 & -- \\
\hline Silica Dioxide $\left(\mathrm{SiO}_{2}\right)$ & 20.53 & -- \\
\hline Alumina Trioxide $\left(\mathrm{Al}_{2} \mathrm{O}_{3}\right)$ & 4.57 & -- \\
\hline Iron Oxide $\left(\mathrm{Fe}_{2} \mathrm{O}_{3}\right)$ & 2.97 & -- \\
\hline Magnesia Oxide $(\mathrm{MgO})$ & 1.66 & $\leq 5.0 \%$ \\
\hline Sulphate $\left(\mathrm{SO}_{3}\right)$ & 2.52 & $\leq 2.8$ if $\mathrm{C}_{3} \mathrm{~A} \geq 5.0 \%$ \\
\hline Loss on Ignition (L. O. I.) & 2.10 & $\leq 4.0 \%$ \\
\hline Insoluble Residue (I. R.) & 0.41 & $\leq 1.5 \%$ \\
\hline Lime Saturation Factor (L. S. F.) & 0.62 & $0.66-1.02$ \\
\hline \multicolumn{3}{|c|}{ Main Compounds (Bogue's equations) } \\
\hline Tricalcium Silicate $\left(\mathrm{C}_{3} \mathrm{~S}\right)$ & 49.8 & -- \\
\hline Dicalcium Silicate $\left(\mathrm{C}_{2} \mathrm{~S}\right)$ & 24.45 & -- \\
\hline Tricalcium Aluminate $\left(\mathrm{C}_{3} \mathrm{~A}\right)$ & 7.44 & -- \\
\hline Tetracalcium Alumino-Ferrite $\left(\mathrm{C}_{4} \mathrm{AF}\right)$ & 10.19 & -- \\
\hline
\end{tabular}

*Tests were carried out in the National Center for Construction Laboratories.

Table 2 Physical Properties of Cement Used Throughout this Investigation.*

\begin{tabular}{|c|c|c|}
\hline $\begin{array}{c}\text { Limits of Iraqi Standard } \\
\text { No.5/1984 }\end{array}$ & $\begin{array}{r}\text { Test } \\
\text { Results }\end{array}$ & Physical Properties \\
\hline$\geq 2300$ & 3760 & $\begin{array}{l}\text { Specific Surface Area, Blaine } \\
\text { Method }\left(\mathrm{cm}^{2} / \mathrm{gm}\right) .\end{array}$ \\
\hline $\begin{array}{l}\geq 45 \mathrm{~min} \\
\leq 10 \mathrm{hrs}\end{array}$ & $\begin{array}{l}2: 35 \\
4: 20\end{array}$ & $\begin{array}{l}\text { Setting Time: } \\
\text {-Initial Setting (hrs.: min) } \\
\text {-Final Setting (hrs.: min) }\end{array}$ \\
\hline $\begin{array}{l}\geq 15 \\
\geq 23\end{array}$ & $\begin{array}{l}29.5 \\
32.6\end{array}$ & $\begin{array}{l}\text { Compressive Strength of Mortar } \\
(\mathrm{MPa}) \text { : } \\
\text { 3-days } \\
\text { 7-days }\end{array}$ \\
\hline$\leq 0.8$ & -0.024 & Soundness \% (Autoclave) \\
\hline
\end{tabular}

*Tests were carried out in the National Center for Construction Laboratories. 
Table 3 Grading and Properties of Natural Fine Aggregate Used in this Investigation."

\begin{tabular}{|c|c|c|}
\hline $\begin{array}{c}\text { Sieve size (mm) According to Iraqi } \\
\text { Standard No.23 }\end{array}$ & $\begin{array}{c}\text { Percentage } \\
\text { Passing }\end{array}$ & $\begin{array}{c}\text { Limits of Iraqi Standard No. } \\
\text { 45/1980 Zone(2) }\end{array}$ \\
\hline 10 & 100 & 100 \\
\hline 4.75 & 100 & $90-100$ \\
\hline 2.36 & 88 & $\underline{75-100}$ \\
\hline 1.18 & 78 & $55-\underline{90}$ \\
\hline 0.6 & 56 & $\underline{85-59}$ \\
\hline 0.3 & 19 & $0-\underline{30}$ \\
\hline 0.15 & 5 & $\leq 5 \%$ \\
\hline Physical Properties and Others & 2 & $\leq 0.5 \%$ \\
\hline Material Passing Sieve $75 \mu \mathrm{m}(\%)$ & 0.3921 & -- \\
\hline Sulphate Content $(\%)$ & 2.54 & -- \\
\hline Fineness Modulus & 2 & -- \\
\hline Absorption (\%) & 2.65 & - \\
\hline Specific Gravity & 1559 & \\
\hline Bulk Density( kg/m $\left.{ }^{3}\right)$ & & \\
\hline
\end{tabular}

*Tests were carried out in the National Center for Construction Laboratories.

Table 4 Grading and Properties of Natural Coarse Aggregate.*

\begin{tabular}{|c|c|c|}
\hline $\begin{array}{c}\text { Sieve Size (mm)According to Iraqi } \\
\text { Standard No.23 }\end{array}$ & $\begin{array}{c}\text { Cumulative } \\
\text { Passing (\%) }\end{array}$ & $\begin{array}{c}\text { Limits of Iraqi Standard No. 45 / } \\
\text { 1984with (5-14)mm }\end{array}$ \\
\hline 14 & 100 & 100 \\
\hline 10 & 72 & $50-85$ \\
\hline 5 & 0 & $0-10$ \\
\hline \multicolumn{2}{|c|}{ Other Properties } \\
\hline Dry Rodded Density $\left(\mathrm{gm} / \mathrm{cm}^{3}\right)$ & 1715 & -- \\
\hline Specific Gravity & 2.63 & $\leq 0.1$ \\
\hline Sulphate Content $(\%)$ & 0.063 & -- \\
\hline Absorption $(\%)$ & 1.7 & \\
\hline
\end{tabular}

*Tests were carried out in the National Center for Construction Laboratories. 
Table 5 Properties of High Range Water Reducer. *

\begin{tabular}{|c|c|}
\hline $\begin{array}{c}\text { Physical and Chemical } \\
\text { Properties }\end{array}$ & Description \\
\hline Appearance & Whitish to straw colored liquid \\
\hline Specific Gravity & 1.07 \\
\hline Chloride Content & Nil \\
\hline PH & $5-8$ \\
\hline Solid Content $(\%)^{1^{*}}$ & 35.6 \\
\hline
\end{tabular}

*According to manufacturer

1 *Tests were carried out in the National Center for Construction Laboratories.

Table 6 Fineness of Crushing Glass Waste Powder after Different Grinding periods.

\begin{tabular}{|c|c|}
\hline Time of Grinding (Minutes) & Fineness (Blain Method) $\mathrm{cm}^{2} / \mathrm{gm}$ \\
\hline 1 & 3100 \\
\hline 5 & 6161 \\
\hline 10 & 7340 \\
\hline 15 & 7057 \\
\hline
\end{tabular}

*Tests were carried out in the National Center for Construction Laboratories.

Table 7 Properties of Glass Powder ${ }^{[7]^{*}}$

\begin{tabular}{|c|c|c|}
\hline $\begin{array}{c}\text { Chemical Composition of } \\
\text { Components }\end{array}$ & Value(\%) & $\begin{array}{c}\text { Requirements of ASTM C-618 } \\
\text { Specifications Class N }\end{array}$ \\
\hline \multicolumn{3}{|c|}{ Chemical Properties } \\
\hline $\mathrm{SiO}_{2}$ & 84.862 & \multirow{3}{*}{$\geq 70$} \\
\hline $\mathrm{Al}_{2} \mathrm{O}_{3}$ & 5.529 & \\
\hline $\mathrm{Fe}_{2} \mathrm{O}_{3}$ & 0.311 & \\
\hline $\mathrm{CaO}$ & 7.934 & --- \\
\hline $\mathrm{SO}_{3}$ & 0.036 & $\leq 4$ \\
\hline $\mathrm{K}_{2} \mathrm{O}$ & 1.251 & --- \\
\hline $\mathrm{TiO}_{2}$ & 0.037 & --- \\
\hline $\mathrm{ZrO} 2$ & 0.011 & --- \\
\hline $\mathrm{Cr}_{2} \mathrm{O}_{3}$ & 0.010 & --- \\
\hline $\mathrm{SrO}$ & 0.008 & --- \\
\hline $\mathrm{CuO}$ & 0.006 & --- \\
\hline $\mathrm{PbO}$ & 0.003 & --- \\
\hline $\mathrm{ZnO}$ & 0.002 & --- \\
\hline \multicolumn{3}{|c|}{ Physical Properties } \\
\hline Retained on a Sieve $45 \mu \mathrm{m}(\%)^{* 1}$ & 9.88 & $\leq 34$ \\
\hline $\begin{array}{c}\text { Fineness(Blain Method) After } 10 \\
\text { Minutes Grinding }\left(\mathrm{cm}^{2} / \mathrm{gm}\right)\end{array}$ & 7340 & --- \\
\hline Specific Gravity & 2.265 & --- \\
\hline Loss on Ignition L.O.I (\%) & 0.41 & $\leq 10$ \\
\hline $\begin{array}{c}\text { Strength Activity Index }(\%)^{* 2} \\
7 \text { days } \\
28 \text { days }\end{array}$ & $\begin{array}{c}80.7 \\
81\end{array}$ & $\begin{array}{l}\geq 75 \\
\geq 75\end{array}$ \\
\hline
\end{tabular}


Table 8 Experimental Concrete Mixtures Containing Different Dosages of Superplasticizer. ${ }^{*}{ }^{[7]}$

\begin{tabular}{|c|c|c|c|c|c|c|}
\hline $\begin{array}{c}\text { Mix } \\
\text { Proportions } \\
\text { by Weight }\end{array}$ & \multirow{2}{*}{$\begin{array}{c}\text { Dosage of } \\
\text { HRWRA } \\
\text { (liter/100kg } \\
\text { of Cement) }\end{array}$} & \multirow[t]{2}{*}{$\begin{array}{l}\text { w/c } \\
\text { Ratio }\end{array}$} & \multirow{2}{*}{$\begin{array}{l}\text { Slump } \\
(\mathrm{mm})\end{array}$} & \multirow{2}{*}{$\begin{array}{l}\text { Water } \\
\text { Reduction } \\
(\%)\end{array}$} & \multicolumn{2}{|c|}{$\begin{array}{l}\text { Compressive } \\
\text { Strength } \\
(\mathrm{MPa})\end{array}$} \\
\hline \multirow{6}{*}{ 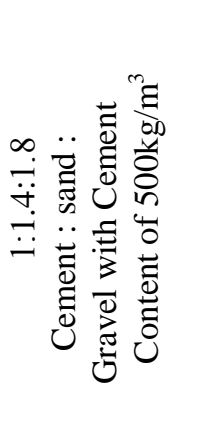 } & & & & & $\begin{array}{l}7 \\
\text { days }\end{array}$ & $\begin{array}{c}28 \\
\text { day }\end{array}$ \\
\hline & 0 & 0.42 & 95 & -- & 28.9 & 40.46 \\
\hline & 0.5 & 0.36 & 102 & 14.28 & 38.1 & 48.6 \\
\hline & 1 & 0.3 & 104 & 28.57 & 41.5 & 53.8 \\
\hline & 1.5 & 0.27 & 102 & 35.71 & 47.7 & 59.6 \\
\hline & 2 & 0.28 & 102 & 33.34 & 43.2 & 55.2 \\
\hline
\end{tabular}

*Tests were carried out in the National Center for Construction Laboratories.

Table (9) Compressive, Splitting Tensile, Flexural Strengths, and Static Modulus of Elasticity for Various Concrete Mixes

\begin{tabular}{|c|c|c|c|c|c|c|c|c|c|}
\hline 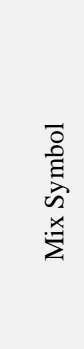 & 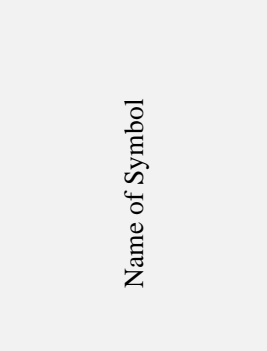 & 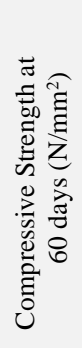 & 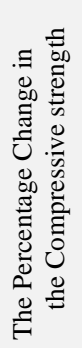 & 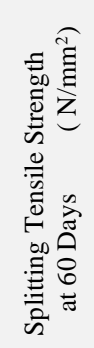 & 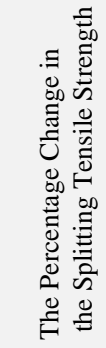 & 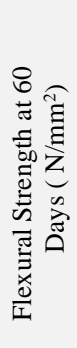 & 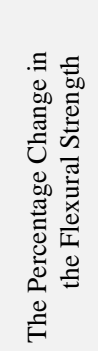 & 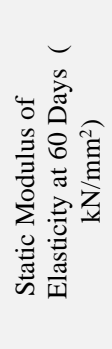 & 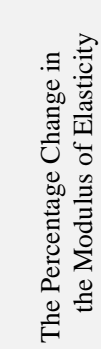 \\
\hline $\mathrm{R}$ & Reference & 64.7 & --- & 3.97 & --- & 5.68 & --- & 45.1 & --- \\
\hline GP10 & $\begin{array}{c}\text { Concrete } \\
\text { Containing } 10 \% \text { Glass } \\
\text { Powder as a } \\
\text { Replacement of } \\
\text { Cement }\end{array}$ & 66.1 & +2.16 & 4.1 & +3.27 & 6.34 & +11.62 & 46.9 & +3.99 \\
\hline GP15 & $\begin{array}{c}\text { Concrete } \\
\text { Containing } 15 \% \text { Glass } \\
\text { Powder as a } \\
\text { Replacement of } \\
\text { Cement }\end{array}$ & 73.3 & +13.29 & 5.41 & +36.27 & 7.65 & +34.68 & 48.8 & +8.20 \\
\hline GP20 & $\begin{array}{c}\text { Concrete } \\
\text { Containing 20\% Glass } \\
\text { Powder as a } \\
\text { Replacement of } \\
\text { Cement }\end{array}$ & 63.5 & -1.85 & 4.89 & +23.17 & 5.75 & +1.23 & 45.6 & +1.11 \\
\hline GP25 & $\begin{array}{c}\text { Concrete } \\
\text { Containing } 25 \% \text { Glass } \\
\text { Powder as a } \\
\text { Replacement of } \\
\text { Cement }\end{array}$ & 60.0 & -7.26 & 3.52 & -11.33 & 4.98 & -12.23 & 43.7 & -3.10 \\
\hline GP30 & $\begin{array}{c}\text { Concrete } \\
\text { Containing } 30 \% \text { Glass } \\
\text { Powder as a } \\
\text { Replacement of } \\
\text { Cement }\end{array}$ & 58.4 & -9.73 & 3.21 & -19.14 & 4.61 & -18.84 & $\begin{array}{r}41.5 \\
3\end{array}$ & -7.92 \\
\hline
\end{tabular}

